\title{
A carta-testamento de Getúlio e a cena da enunciação
}

\author{
Maria Eduarda Giering ${ }^{1}$
}

\begin{abstract}
We analyze Getulio Vargas' testament-letter, characterized by a double genrecity (RODRIGUES et al, 2012), under the perspective of the "enunciation scene" (MAINGUENEAU, 2001; 2004; 2006), which associates, according to the linguist, three speech scenes: the "comprehensive", the "generic" and the "scenography" ones. For the author, a text is not a set of inert signs, but it is instead the trail left by a discourse in which speech is staged. The purpose of this paper is to analyze the testament-letter as a discourse that aimed to persuade and thrill its interlocutors instituting the enunciation scene that legitimizes it. We consider the text under the perspective of the political comprehensive scene and of the epistolary generic scene, identifying the participants' roles, the way of inscription in time and space, the material support, the discursive aim. Towards the analysis of the scenography constructed by the enunciator, considering the discursive genre "testament-letter" under discussion and the discursive purposes aimed, we focus the enunciative and narrative organization mode presented by the letter, as well as the marks of pragmatic modeling (modalities). By means of the discursive staging of the testament-letter, an ethos - an identity - is created, through which Vargas is now identified as a heroic symbol of resistance.
\end{abstract}

Keywords: testament-letter; enunciation scenes; narrative mode; modalities; ethos.

Resumo: Estudamos a carta-testamento de Getúlio Vargas, caracterizada por uma dupla genericidade (RODRIGUES et al, 2012), sob a perspectiva da "cena de enunciação" (MAINGUENEAU, 2001; 2004; 2006), que associa, segundo o linguista, três cenas de fala: a "englobante", a "genérica" e a "cenografia". Para o autor, um texto não é um conjunto de signos inertes, mas o rastro deixado por um discurso em que a fala é encenada. $\mathrm{O}$ objetivo do trabalho é analisar a carta-testamento como um discurso que pretendeu convencer e emocionar seus interlocutores instituindo a cena da enunciação que a legitima. Consideramos o texto sob a perspectiva da cena englobante política e da cena genérica epistolar, identificando os papeis dos participantes, o modo de inscrição no tempo e espaço, o suporte material, a finalidade discursiva. Para a análise da cenografia construída pelo enunciador, tendo em vista o gênero discursivo "carta-testamento" em questão e os fins discursivos almejados, enfocamos o modo de organização enunciativo e narrativo da carta, bem como as marcas de modalizações pragmáticas (modalidades). Verificamos que se cria, pela encenação discursiva da cartatestamento, um ethos, uma identidade, por meio da qual Vargas passa a ser identificado como um símbolo heroico de resistência.

Palavras-Chave: carta-testamento; cenas da enunciação; modo narrativo; modalidades; ethos. 
Introdução

A carta-testamento de Getúlio Vargas (doravante GV) é um rico documento para ser estudado sob a perspectiva da cena enunciativa que o envolve, uma vez que se trata de um texto produzido em circunstâncias contundentes, o suicídio de $\mathrm{GV}$, que provocou infindáveis repercussões ao longo da história do Brasil.

Antes de se suicidar por volta de 8h30min do dia 24 de agosto de 1954, GV escreveu o texto que historicamente ficou conhecido como carta-testamento. A autoria deste documento, na verdade, ainda hoje é polêmica. Existem duas versões desta carta: uma manuscrita, bastante concisa, e outra mais longa, datilografada, que foi distribuída para a imprensa como a mensagem oficial do político ao povo brasileiro. De acordo com Heymann (2004), a autoria chegou a ser atribuída ao jornalista José Soares Maciel Filho, redator de grande parte dos discursos de GV. De qualquer forma, o texto datilografado foi o publicizado logo após sua morte e o que gerou comoção nacional. É a ele que dedicamos nosso estudo.

Lira Neto (2004) narra o que aconteceu naqueles dias, quando, segundo o relato de familiares e colaboradores, ao lado do corpo de GV foi encontrada a cópia de uma carta com sua assinatura, dirigida ao povo brasileiro:

Pelo telefone, claramente emocionado, o ministro da Fazenda, Oswaldo Aranha, leu para a Rádio Nacional a carta-testamento encontrada na mesinha de cabeceira do presidente morto: "Eu vos dei a minha vida. Agora ofereço a minha morte. Nada temo. Serenamente dou o primeiro passo no caminho da eternidade e saio da vida para entrar na história". O relógio indicava que faltavam 15 minutos para as 9 da manhã daquele 24 de agosto de 1954. Nunca o país assistira a tamanha comoção popular como a que veio logo após a divulgação da notícia: Getúlio Vargas se matara, em seu quarto, por volta de $8 \mathrm{~h} 30$, com um tiro no peito. Multidões saíram às ruas. Enfurecidos, manifestantes depredaram a sede da Tribuna da Imprensa, o jornal de Carlos Lacerda, mais furibundo dos adversários de Getúlio. Uma massa humana de 100 mil pessoas, a maioria em pranto incontrolável, desfilou diante do caixão do presidente, velado no próprio Palácio do Catete, sede do governo federal, no Rio. A imprensa noticiou que cerca de 3 mil pessoas presentes ao velório, vítimas de desmaios, mal-estares, crises nervosas e problemas de coração, precisaram ser atendidas pelo serviço médico do palácio. Na enfermaria, o estoque de calmantes esgotou-se em minutos. O país inteiro quedou em estado de choque. Ninguém esperava por aquele desfecho para a crise que se abatera como uma nuvem negra sobre o governo, apesar de o próprio Getúlio ter dito, dias antes, com todas as letras: "Só morto sairei do Catete". (NETO, 2004)

A repercussão da morte e da mensagem de Vargas foi, como vemos, contundente. No texto em que ele explicava as razões que o levaram ao gesto extremo, GV colocava-se no papel de defensor, representante e libertador do povo. Conforme Heymann (2004), o presidente buscava, com sua morte, sagrar-se mártir do povo e consolidar seu nome no panteão político brasileiro, associando-o definitivamente à bandeira dos interesses nacionais e do trabalhismo. Para a autora, o suicídio e a irradiação da carta para todo o território nacional foram capazes de produzir sensíveis alterações nos rumos políticos do país, pois evitaram que se concretizasse o golpe de estado que estava sendo preparado.

Estudamos o documento do ponto de vista da "cena da enunciação" em que ele se insere e que, ao mesmo tempo, cria. Nossa questão, nesse enfoque da carta-testamento, é identificar elementos da cena de enunciação que permitem a interpretação dos historiadores de que a carta tem "um tom passional e dramático" (D'ARAÚJO, 2012), o que 
levou muitas pessoas ao desespero, transforma-a em ícone. O objetivo é analisá-la como um discurso que pretendeu convencer e emocionar seus interlocutores instituindo a cena da enunciação que a legitima. Para isso, nos embasamos em Maingueneau (2001; 2004; 2006), que associa à cena da enunciação três cenas de fala: a "englobante", a "genérica" e a "cenografia". Para o autor, um texto não é um conjunto de signos inertes, mas o rastro deixado por um discurso em que a fala é encenada (MAINGUENEAU, 2001, p.85).

\section{A base teórica}

Ao adotarmos a noção de "cena de enunciação", postulada por Maingueneau (2010), analisamos a carta-testamento como uma enunciação que se insere num espaço instituído, definido por um gênero discursivo, e como um discurso que constrói ou instaura seu próprio espaço de enunciação. Para o linguista, "enunciar não é somente expressar ideias, é também tentar construir e legitimar o quadro da enunciação" (MAINGUENEAU, 2001, p. 93).

Cabe a ressalva de que a cena da enunciação não corresponde a uma "situação de comunicação", pois, conforme o linguista, a noção de "cena" remete à "representação que um discurso faz de sua própria situação de enunciação" (MAINGUENEAU, 2004, p. 95). Numa aproximação ao quadro teórico da Semiolinguística de Charaudeau (2008), a encenação que postula Maingueneau se relaciona ao espaço interno da comunicação, ao lugar no qual o locutor, por meio de sua fala, assume e atribui ao interlocutor um papel. Em vista disso, Maingueneau (2004) não emprega termos como "situação de comunicação" ou "contexto", já que deseja se distanciar de uma concepção sociologista da enunciação. Não se trata de interpretar a situação como entorno físico ou social no qual se encontram os interlocutores, alerta o linguista (MAINGUENEAU, 2010).

A situação de enunciação é "o sistema onde são definidas as três posições fundamentais de enunciador; de coenunciador e de não-pessoa", afirma Maingueneau (2010, p. 201), seguindo a teoria enunciativa benvenistiana. Nessa concepção, as coordenadas pessoais da situação de enunciação têm como base a marcação de dêiticos espaciais e temporais. Dessa forma, "apreender uma situação de discurso como cena de enunciação é considerá-la 'do interior', através da situação que a fala pretende definir" (MAINGUENEAU, 2010, p. 205), explica. Trata-se de apreender o quadro que a situação de discurso mostra "no movimento mesmo de seu desdobramento".

Isso quer dizer que, na análise que faremos da cena da enunciação da carta- testamento de GV, empregaremos a noção de enunciação como "contexto no interior do qual se desenvolve o discurso" (MAINGUENEAU, 2010, p. 195) e com as categorias de enunciador e coenunciador como seres do discurso. Além disso, convém ressaltar a noção de cena que está em jogo. Conforme Maingueneau (2004), ela implica a representação que um discurso faz de sua própria enunciação.

A cena da enunciação, de acordo com o linguista (MAIGUENEAU, 2006), associa três cenas de fala: a cena englobante, a genérica e a cenografia.

A cena englobante corresponde ao que ele denomina "tipo de discurso", termo que possui aqui um significado restrito, ou seja, é considerado como "um setor de produção verbal de uma sociedade com um dispositivo de comunicação particular (implicando papéis, um canal, temas etc. particulares)" (MAINGUENEAU, 2004, p. 468). Trata-se do estatuto pragmático do tipo de discurso. Uma enunciação política, exemplifica o linguista, implica "um cidadão" dirigindo-se a outros "cidadãos", caracterização que ele reconhece poderia ser considerada mínima demais. No entanto, adverte (MAINGUENEAU, 
2001, p. 86), essa caracterização nada tem de intemporal, pois é ela que define a situação dos parceiros e um quadro espaço-temporal. Ele explica:

Em numerosas sociedades do passado, não existia cena englobante especificamente política. Não se pode tampouco falar de cena administrativa, publicitária, religiosa, literária etc., para qualquer sociedade e em qualquer época (MAIGUENEAU, 2001, p. 86).

A cena englobante, de fato, não é suficiente para especificar as atividades discursivas nas quais se encontram os sujeitos. É preciso o aporte dos gêneros de discurso com seus rituais sócio-linguageiros para definir as várias cenas genéricas (MAIGUENEAU, 2006).

Os tipos de discurso podem recobrir diversos gêneros discursivos. No discurso político atual, temos, por exemplo, debates televisivos, panfletos, propaganda eleitoral, entre outros. Trata-se da chamada cena genérica, ou seja, de um contrato associado ao gênero ou subgênero de discurso. Cada gênero implica uma cena específica, que institui "papeis para seus parceiros, circunstâncias (em particular um modo de inscrição no espaço e no tempo), um suporte material, um modo de circulação, uma finalidade etc." (MAINGUENEAU, 2004, p. 96). Os gêneros discursivos, porém, como "instituições de fala sócio-historicamente definidas” (MAINGUENEAU, 2006, p. 112), possuem grande instabilidade, não se deixando, portanto, apreender em taxionomias compactas, adverte o linguista. Este é o caso de nosso objeto de estudo, a carta-testamento, situado na intersecção de pelo menos dois gêneros.

Um quadro cênico é definido pelas cenas englobante e genérica. Para Maingueneau (2001, p. 87), institui-se, assim, um espaço estável no interior do qual o enunciado adquire sentido para o leitor/ouvinte.

Há gêneros de discursos que se resumem a essas duas cenas. É o caso de documentos oficiais como os textos de lei, por exemplo. No entanto, a maioria dos gêneros exige a escolha de uma cenografia, ou seja, "eles se esforçam para atribuir a seu destinatário uma identidade em uma cena de fala" (MAIGUENEAU, 2004, p. 97). A cenografia, explica o linguista, desloca o quadro cênico para segundo plano e faz com que o leitor passe a aceitar o lugar que o enunciador designa a ele. A cenografia não é indiferente: “o discurso, desenvolvendo-se a partir de sua cenografia, pretende convencer instituindo a cena de enunciação que o legitima" (MAIGUENEAU, 2006, p. 113).

A cenografia implica um processo de enlaçamento paradoxal, postula o linguista: "a enunciação, ao se desenvolver, esforça-se por instituir progressivamente seu próprio dispositivo de fala" (MAINGUENEAU, 2006, p. 114). Ele explica:

A cenografia é, ao mesmo tempo, origem e produto do discurso; ela legitima um enunciado que, retroativamente, deve legitimá-la e estabelecer que essa cenografia de onde se origina a palavra é a cenografia requerida para contar uma história, para denunciar uma justiça etc. (MAINGUENEAU, 2006, p. 114).

É a própria cenografia que autentica sua existência como enunciado. É na sua progressão que o enunciando vai se legitimando na medida em que aciona um dispositivo de fala e, retroativamente, se valida. Em toda cena de enunciação, os enunciados recorrem ao que Maingueneau chama de cena validada, o que dá status de existência a eles. Para o autor, as cenografias apoiam-se em cenas validadas, ou seja, "já instaladas na memória coletiva, seja a título de modelos que se rejeitam ou de modelos que se valorizam" (MAINGUENEAU, 2001, p. 92). 
Maingueneau (2006) distribui os gêneros de discurso numa linha contínua em dois polos extremos: de um lado, os gêneros que se limitam à sua cena genérica; de outro lado, os que "por natureza exigem a escolha de uma cenografia" (MAINGUENEAU, 2006, p. 115). Os gêneros do discurso publicitário, por exemplo, porque precisam captar o imaginário de seu destinatário, mobilizam cenografias variadas. Para isso, atribuem-lhe "uma identidade por intermédio de uma cena de fala que seja valorizadora para o enunciador assim como para o coenunciador" (MAINGUENEAU, 2006, p. 115). Em uma notícia de jornal sobre política, lembram Nascimento e Cano (2011), a cena genérica "notícia" é colocada muitas vezes em segundo plano quando enlaça o destinatário por meio de uma "denúncia". Neste caso, o jornalista passa a desempenhar o papel de "denunciador", fato que desata uma rede de compreensão textual bem diferente daquela comum à notícia.

Associa-se aqui a noção de ethos discursivo (MAINGUENEAU, 2001, p. 97), quando, por meio da enunciação, "revela-se a personalidade do enunciador". Para Maingueneau (2006, p. 68):

A cenografia, com o ethos da qual participa, implica um processo de enlaçamento: desde sua emergência, a fala é carregada de um certo ethos, que, de fato, se valida progressivamente por meio da própria enunciação (MAINGUENEAU, 2006, p. 68).

O texto possui um tom que dá autoridade ao que é dito, que permite ao leitor "construir uma representação do corpo do enunciador, que, evidentemente, não é do corpo do autor efetivo" (MAINGUENEAU, 2001, p. 99)

Maingueneau (2006) lembra que, em última instância, a questão do ethos está ligada à construção da identidade. "Cada tomada da palavra implica ao mesmo tempo levar em conta representações que os parceiros fazem um do outro, e a estratégia de fala de um locutor que orienta o discurso de forma a sugerir através dele uma certa identidade", explica ele. (MAINGUENEAU, 2006, p. 56)

Em contrapartida, a especificidade do ethos remete à figura de um 'fiador' que, por meio de sua fala, se dá uma identidade que está de acordo com o mundo que ele supostamente faz surgir. O linguista postula que essa problemática do ethos permite contestar a redução da interpretação a uma simples decodificação. Para ele, "alguma coisa da ordem da experiência sensível funciona no processo de comunicação verbal. As 'ideias' suscitam a adesão do leitor por meio de uma maneira de dizer que é também uma maneira de ser" (MAINGUENEAU, 2006, p. 70).

De fato, tudo que cerca a carta-testamento de GV leva à ideia da construção de uma cenografia dramaticamente organizada com vistas a tocar a sensibilidade do leitor. As reações emocionadas da população brasileira mostram que essa cenografia teve êxito.

\section{A cena da enunciação na carta-testamento de GV}

A cena que engloba a carta-testamento é a política. O enunciador é o presidente da república, dirigindo-se a seus destinatários, os cidadãos do Brasil de 1954. Esse é um período conturbado, com uma atmosfera acusatória que pairava contra o presidente e que havia levado à queda de sua popularidade.

Os jornais, ao publicarem, junto ao anúncio da morte de GV, notícia sobre a carta- testamento deixada pelo presidente, referem-se ao documento como "último bilhete de Getúlio"; "a derradeira mensagem"; "a mensagem"; "o bilhete". Historicamente, porém, o documento ficou conhecido por carta-testamento, designação que assinala sua dupla genericidade. 
Que propriedades se verificam no documento deixado por GV para que ele tenha sido considerado como carta-testamento? Como ele se inscreve no espaço e no tempo? Que papeis ela institui? Qual sua finalidade?

Conforme Rodrigues et al (2012), embora o texto acessível para estudo não contenha indicação de assinatura, lugar, data ou vocativo inicial, características do gênero epistolar, o documento é considerado uma carta. Os pesquisadores atribuem essa designação às condições de produção e ao contexto político e histórico. A carta de GV é um documento pessoal, mas ao mesmo tempo "público", uma vez que se dirige ao "povo brasileiro", que é evocado em várias passagens por meio de formas pronominais da $2^{\mathrm{a}}$ pessoa do plural, por exemplo: "Nada mais vos posso dar a não ser meu sangue". Além disso, Rodriguez et al. (2012) chamam a atenção para o tom emocionado do enunciador, que aproxima o documento da carta pessoal.

A carta tem também características do gênero testamento. Afirma GV: "Deixo à sanha de meus inimigos o legado de minha própria morte". Bellotto assim define esse gênero discursivo:

Documento diplomático testemunhal de assentamento, horizontal, notarial. Disposição ou declaração solene da vontade do testador sobre aquilo que deseja que se faça, depois da sua morte, com seus bens e fortuna. (BELLOTTO, 2002, p. 89)

Estudos sobre a repercussão histórica da morte de GV e da carta-testamento tratam da contribuição do documento para a construção da ideia de um legado de Vargas (Heymann, 2004). Nesse sentido, o gênero testamento se apresenta em uma de suas finalidades: a disposição de GV de deixar, após sua morte, um legado ("Meu sacrifício ficará para sempre em sua alma e meu sangue será o preço do seu resgate"). Conforme Michaelis (1998, p. 1237), um legado é "disposição, a título gracioso, via pela qual uma pessoa confia a outra, em testamento, um determinado benefício, de natureza patrimonial; doação "causa-mortis".

Os estudiosos de GV falam comumente em "herança varguista", termo que está no âmbito da carta-testamento. Mazzei (2014) considera que vários fatores devem ser levados em conta para facilitar o entendimento da herança de Vargas (populismo, nacionalismo) e um ponto de partida é a carta-testamento. Para o sociólogo, "o conteúdo e a linguagem do documento sugerem um registro típico do seu estilo, caracterizado pela relação entre o EU (governante) e o POVO (governado)" (MAZZEI, 2014).

A carta-testamento não foi, portanto, uma simples mensagem para informar os interlocutores sobre a razão do gesto extremo do suicídio. Na verdade, trata-se de um documento em que o enunciador se assume como um personagem cuja trajetória é a de constantes embates políticos que culminam com sua morte heroica. Para isso, uma rica cenografia é mobilizada visando a persuadir os destinatários e, mais fortemente, a emocioná-los.

\section{A cenografia}

A carta-testamento organiza uma cuidadosa cenografia para denunciar os interesses econômicos que teriam impedido GV de fazer um governo mais eficaz em prol dos pobres e as conspirações e humilhações de que vinha sendo vítima. Para D’Araújo (2012),

na carta há uma imagem conspiratória da história, a noção de que interesses subalternos, escusos, conspiravam contra seu projeto de redenção dos brasileiros. Este tom passional e dramático transforma a carta em ícone, em símbolo do que seus seguidores poderiam conceber como o melhor projeto para o Brasil: o nacionalismo e o trabalhismo getulista. 
O enunciador coloca-se como um "denunciador" das forças ocultas que o impedem de governar para o povo, mas também como vítima dessa situação e em busca de um gesto heroico que o libere, que transforme a situação política ainda que sem sua presença física.

Buscamos na carta-testamento (em anexo) as marcas linguístico-discursivas que evidenciam a cenografia mobilizada pelo enunciador para sua autenticação. Para isso, focalizamos na organização enunciativa e narrativa da carta, empregando as categorias advindas da Semiolinguística (Charaudeau, 2008) relativas ao Modo de Organização Enunciativo (MOE) e as respectivas categorias modais, e ao de Modo de Organização Narrativo (MON). O MOE permite observar a maneira como o enunciador age na encenação do ato de comunicação que constitui a carta; o MON possibilita a construção da lógica narrativa, na qual os actantes desempenham papeis e os processos unem esses actantes entre si, dando uma orientação funcional, conforme certos princípios de organização.

\section{A organização enunciativa}

A construção enunciativa da carta-testamento é predominantemente elocutiva (CHARAUDEAU, 2008), ou seja, revela-se fortemente o ponto de vista do locutor, produzindo, dessa forma, o efeito de modelizar subjetivamente o que é dito. No comportamento elocutivo, o ponto de vista sobre o mundo pode se especificar, conforme Charaudeau (2008), como um ponto de vista (1) do modo de saber, (2) de avaliação, (3) de motivação, (4) de engajamento e (5) de decisão. Na carta, observa-se o emprego da primeira pessoa do singular e um ponto de vista de engajamento, que especifica o grau de adesão ao que é dito. Revela-se a modalidade da Declaração, em que o locutor detém um saber, supõe que o interlocutor ignora esse saber, além de dizer que esse saber existe em sua verdade. O interlocutor, por sua vez, não está implicado e é testemunha da declaração do locutor.

A Declaração, na carta, expressa a variante da Revelação. O locutor, assumindo uma posição de denunciador, mostra que "tinha conhecimento de um saber que outros mantinham voluntariamente oculto" (CHARAUDEAU, 2008, p. 98). Mais precisamente, revela-se uma verdade conforme o ponto de vista do enunciador em tom de desabafo, com a clara intenção de desvelar a situação vivida naquele momento por ele, denunciada a ação dos grupos contrários. Eis algumas passagens que exemplificam a modalidade de Declaração/Revelação, embora a carta como todo apresente essa modalidade:

(3) Precisam sufocar a minha voz e impedir a minha ação, para que eu não continue a defender, como sempre defendi, o povo e principalmente os humildes.

(16) Tentamos defender seu preço e a resposta foi uma violenta pressão sobre a nossa economia, a ponto de sermos obrigados a ceder.

Observamos na carta também a modalidade do Querer, que define, conforme Charaudeau (2008), os seguintes papeis para o locutor e para o interlocutor. O locutor estabelece, com seu enunciado, uma ação a fazer cuja realização não depende dele; diz que está numa situação de carência que gostaria de ver preenchida, o que significa que vê a ação a realizar lhe sendo benéfica; revela, ao mesmo tempo, que não tem o poder de preencher essa carência. O interlocutor, por sua vez, não está implicado no ato de enunciação e é testemunha de um "querer" expresso pelo locutor.

$\mathrm{Na}$ carta-testamento, o enunciador narra seu querer, que é frustrado a cada vez. Diz que, embora ele tenha querido realizar ações consideradas a favor do povo brasileiro, como, por exemplo, no segmento (8), elas foram sempre obstaculizadas. Notamos, na 
verdade, que a modalidade do Querer vem associada à modalidade da Declaração/Revelação. Por exemplo:

(8) Quis criar liberdade nacional na potencialização das nossas riquezas através da Petrobrás e, mal começa esta a funcionar, a onda de agitação se avoluma.

É interessante considerar, na expressão dessas modalidades, que o enunciador denuncia, pela negação, o querer do inimigo, segundo seu ponto de vista, como em (14):

(14) Não querem que o trabalhador seja livre.

A modalidade da Obrigação também se revela no documento. Os papeis relativos a esta modalidade, conforme Charaudeau (2008), são, para o locutor, estabelecer, com seu enunciado, uma ação a fazer cuja realização depende apenas dele; dizer que deve realizar esta ação, seja por coerções do próprio locutor (interna), seja por pressão externa. O interlocutor, por sua vez, não está implicado e é testemunha da "obrigação" do locutor.

$\mathrm{Na}$ carta-testamento, diante da impossibilidade de realizar ações tendo em vista os impedimentos criados pelo inimigo, o enunciador se coloca na obrigação moral de agir de qualquer forma, a fim de modificar a situação limite e aparentemente sem saída que ele denuncia viver. Vemos isso de forma clara nos segmentos (22) e (27):

(22) Nada mais vos posso dar, a não ser meu sangue.

(27) E aos que pensam que me derrotaram respondo com a minha vitória.

Do ponto de vista elocutivo, em que o enunciador se coloca na relação consigo mesmo, como vemos, GV se apresenta não apenas como detentor de um saber que ele denuncia a seu leitor, mas também como alguém que é dotado de um querer-fazer que é sempre frustrado pelo querer contrário do inimigo. Diante disso, no entanto, ele assume, ao final, o papel de quem se coloca na obrigação de agir de qualquer forma para poder vencer. Percebemos, nesta obrigação de ordem moral, ainda que interna, ou seja, mesmo que dependa unicamente dele e não implique com isso o interlocutor (o que seria próprio de um comportamento alocutivo), uma derradeira demonstração de força. Na verdade, como ele não tem mais poder suficiente para agir em favor de seu interlocutor e contra seus inimigos, resta a ação radical do suicídio, vista como um exercício extremado de força, o que se percebe claramente em (31):

(31) E aos que pensam que me derrotaram respondo com a minha vitória.

\section{Modo de organização narrativo}

A organização enunciativa vem acompanhada de uma organização narrativa em que se revelam os papeis assumidos por vários protagonistas colocados em cena.

Na carta-testamento, o enunciador narra seu percurso de reveses, até chegar ao gesto do suicídio. Por meio da organização narrativa, ele constrói um mundo ou o revela ao interlocutor, numa lógica que justifica e glorifica sua ação derradeira.

Ao narrar sua história, ele atribui papeis narrativos a si e a seus oponentes, de forma a estabelecer actantes que agem e que sofrem ações. Correlativamente, ocorrem os processos narrativos, que são semantizações das ações em relação aos papeis narrativos dos actantes e sua qualificação (CHARAUDEAU, 2008). 
Assim, verificam-se, na carta, os seguintes actantes narrativos: o Benfeitor (transmite um benefício), o Agressor (comete um malefício), o Aliado (associa-se a um outro actante para auxiliá-lo ou defendê-lo), a Vítima (o actante é afetado negativamente pela ação de outro actante).

A lógica narrativa, na qual uma sucessão de acontecimentos está ligada por uma reação de solidariedade (princípio de coerência), só tem sentido por estar relacionada a um encadeamento dirigidos a um fim, como destaca Charaudeau (2008, p. 166). Trata-se do princípio de intencionalidade ou de motivação. As ações ou acontecimentos agrupam-se em sequências, as quais se ordenam num princípio de encadeamento, e ocorrem num enquadramento espaço-temporal, seguindo um princípio de localização.

De acordo com o princípio de intencionalidade, uma sequência narrativa assim se organiza:

1. Um estado inicial de virtualidade de ação, no qual nasce uma Falta, abre a possibilidade de um processo como Busca de preenchimento da Falta;

2. Um estado de atualização da Busca que consiste em tentar obter o Objeto que preencherá a Falta;

3. Um estado Final da realização do processo, que se fecha por obtenção (êxito) ou não (fracasso) do objeto da Busca. (CHARAUDEAU, 2008, p. 169)

Na carta-testamento, o enunciador, empregando a primeira pessoa do singular, colocase como Benfeitor que transmite um benefício ao povo:

(6) Iniciei o trabalho de libertação e instaurei o regime de liberdade social.

A par disso, ele denuncia quem são seus Oponentes, contrários a seus projetos: (1) as forças e os interesses contra o povo; (9) grupos nacionais revoltados contra o regime de garantia do trabalho; (23) as aves de rapina;(31) os que pensam que me derrotam. Também nomeia o actante-aliado do oponente: (9) A campanha subterrânea dos grupos internacionais.

O povo, por sua vez, assume o papel de aliado do benfeitor: (8) Voltei ao governo nos braços do povo.

O enunciador, ao sofrer uma ação, ou seja, quando é negativamente afetado pela ação dos oponentes, assume o papel de actante-vítima, expressando-se em primeira pessoa:

(1) Mais uma vez, a forças e os interesses contra o povo coordenaram-se e novamente se desencadeiam sobre mim. (2) Não me acusam, insultam; não me combatem, caluniam, e não me dão o direito de defesa. (3) Precisam sufocar a minha voz e impedir a minha ação, para que eu não continue a defender, como sempre defendi, o povo e principalmente os humildes.

O actante-vítima reage, finalmente, atuando, segundo ele acredita, contra seu agressor e em favor de seu aliado, o povo: (23) eu ofereço em holocausto a minha vida; (28) Meu sacrificio..."; (40) Agora vos ofereço a minha morte.

Observando as sequências narrativas e os processos que ocorrem ao longo da carta, verificamos a existência de um Estado Inicial de falta. A narrativa inicia com a descrição realizada pelo enunciador da situação (que se repete: Mais uma vez; novamente) em que ele se encontra exercendo o papel de actante-vítima (devido a agressões do oponente contra ele) por defender o povo/os humildes: 


\section{Conexão Letras}

(1) Mais uma vez, a forças e os interesses contra o povo coordenaram-se e novamente se desencadeiam sobre mim. (2) Não me acusam, insultam; não me combatem, caluniam, e não me dão o direito de defesa. (3) Precisam sufocar a minha voz e impedir a minha ação, para que eu não continue a defender, como sempre defendi, o povo e principalmente os humildes. (Negritos da autora)

No segundo parágrafo, o enunciador narra episódios anteriores ao momento da fala. As ações positivas descritas pelo enunciador são sempre obstaculizadas, o que gera algum tipo de consequência, ou seja, uma outra ação.

\section{Episódio 1:}

- AÇÃO:(5) Depois de decênios de domínio e espoliação dos grupos econômicos e financeiros internacionais, fiz-me chefe de uma revolução e venci. (6) Iniciei o trabalho de libertação e instaurei o regime de liberdade social.

- PROBLEMA: (7) Tive de renunciar.

- AÇÃO: (8) Voltei ao governo nos braços do povo.

Trata-se de um processo em que o enunciador coloca-se como benfeitor que sofre uma agressão do oponente; o actante-aliado do benfeitor, papel exercido pelo povo, o defende, recolocando-o no poder.

\section{Episódio 2:}

- Ação: (9) Implantação do regime de garantia de trabalho

- Problema: (9) A campanha subterrânea dos grupos internacionais aliou-se à dos grupos nacionais revoltados contra o regime de garantia do trabalho.

- Ação: (10) Implantação da lei de lucros extraordinários

- Problema: (10) A lei de lucros extraordinários foi detida no Congresso.

- Ação: (11) Revisão do salário mínimo

- Problema: (11) Contra a justiça da revisão do salário mínimo se desencadearam os ódios.

- Ação: (12) Quis criar liberdade nacional na potencialização das nossas riquezas através da Petrobrás.

- Problema: (12) e, mal começa esta a funcionar, a onda de agitação se avoluma.

- Ação: (13) Criação da Eletrobrás

- Problema: (13) A Eletrobrás foi obstaculada até o desespero.

Comentário conclusivo do enunciador ao final do segundo parágrafo: (14) Não querem que o trabalhador seja livre.

Verificamos, neste Episódio, um processo em que o Benfeitor sofre sucessivos ataques do Oponente, os quais o impedem de dar continuidade às ações de benfeitoria.

No $3^{\circ}$ parágrafo, temos o $3^{\circ}$ Episódio, em que o enunciador descreve a situação negativa na qual ele assumiu o governo após a renúncia e narra sua impotência diante da ação do oponente.

Episódio 3:

Situação descrita: 
(16) Assumi o Governo dentro da espiral inflacionária que destruía os valores do trabalho.

(17) Os lucros das empresas estrangeiras alcançavam até 500\% ao ano.

(18) Nas declarações de valores do que importávamos existiam fraudes constatadas de mais de 100 milhões de dólares por ano.

(19) Veio a crise do café, valorizou-se o nosso principal produto.

Ação do benfeitor (ação que não se realizou (verbo tentar):

(20) Tentamos defender seu preço

Reação do oponente:

(20) e a resposta foi uma violenta pressão sobre a nossa economia

Efeito da reação do oponente:

(20) a ponto de sermos obrigados a ceder.

Vemos aqui o processo em que o Benfeitor, apesar de procurar agir a favor do povo (pela sua independência), é contrariado pelas ações do Oponente. $\mathrm{O}$ enunciador coloca-se no papel de Vítima.

No quarto parágrafo, o enunciador, inicialmente narra sua situação de vítima, que luta incessantemente e em vão contra a pressão do Oponente.

(21) Tenho lutado mês a mês, dia a dia, hora a hora, resistindo a uma pressão constante, incessante, tudo suportando em silêncio, tudo esquecendo, renunciando a mim mesmo, para defender o povo, que agora se queda desamparado.

Na sucessão, o actante-vítima anuncia sua reação inesperada contra o adversário e em benefício do interlocutor, o povo:

(22) Nada mais vos posso dar, a não ser meu sangue. (23) Se as aves de rapina querem o sangue de alguém, querem continuar sugando o povo brasileiro, eu ofereço em holocausto a minha vida.

O Estado final ocorre nos quinto e sexto parágrafos, onde tem lugar o processo no qual o Benfeitor, que se situava no papel narrativo de Vítima pelas ações do Oponente, reverte o estado de degradação por meio da resolução do problema. Ao anunciar, como resposta, seu suicídio, ele finalmente intervém na situação e se coloca como vitorioso:

(31) E aos que pensam que me derrotaram respondo com a minha vitória.

Podemos assim esquematizar a sequência narrativa da carta-testamento:

\begin{tabular}{|c|c|}
\hline Estado Inicial & Situação de degradação. Derrota. \\
\hline Estado de atualização - Busca & Busca da vitória: suicídio \\
\hline Estado Final & Ação exitosa. Vitória. \\
\hline
\end{tabular}

A cientista política Maria Celina D’Araújo (2014) expressa a dimensão deste ato:

O impacto do suicídio de Vargas foi surpreendente. Primeiro pela ousadia do gesto, segundo, pela emoção e pelo ambiente de tragédia que tomou conta do país, terceiro, pelo desnorteamento que produziu em seus adversários. Foi um ato político, talvez o maior concebido por Getúlio, que sabia poder contar com a simpatia do povo. (D'ARAÚJO, 2004) 


\section{Considerações finais}

O texto possui um tom dramático, envolvendo vilões e um herói que luta contra seus inimigos. A organização enunciativa marcada pela revelação de verdades conforme o ponto de vista do enunciador e a assunção do papel de benfeitor que tem como aliado o povo torna o enunciador fiador do que é dito, o que ele diz é verdadeiro e se torna exatamente assim, ou seja, os oponentes, que o bombardeavam sem tréguas são identificados como inimigos que visavam derrotar as conquistas que ele assegurava ao povo brasileiro; o enunciador figura como salvador, capaz de um sacrifício extremo. A sucessão de episódios constrói a trajetória da personagem que o enunciador cria para si e para os outros e justifica a obrigação da ação do suicídio, considerado como um ato de libertação tanto dele quanto do povo brasileiro. Cria-se, portanto, pela encenação discursiva expressa na carta-testamento, um ethos, uma identidade, por meio da qual GV passa a ser identificado, conforme asseguram as palavras de Lira Neto (2014, p. 346): "Em vez de significar um gesto de fraqueza e covardia, a autoimolação de Getúlio o tornava mártir e, para o imaginário coletivo nacional, um símbolo heroico da resistência".

\section{Referências}

BELLOTO, H. L. Como fazer análise diplomática e análise tipológica de documento e análise tipológica de documento de arquivo. São Paulo: Arquivo do Estado de São Paulo/Imprensa Oficial, v.8, 2002.

CHARAUDEAU, P. Linguagem e discurso: modos de organização. São Paulo: Contexto, 2008.

D'ARAÚJO, M.C. A herança de Vargas: a crise de 1954 e a carta testamento. São Paulo: A era Vargas. FGV-CPDOC, 2004. Disponível em: http://cpdoc.fgv.br/producao/dossies/ Jango/artigos/NoGovernoGV/A_heranca_de_Vargas. Acesso em: 04 jun. 2014. HEYMANN, L.Q. A carta-testamento e o legado de Vargas. São Paulo: A era Vargas. FGV-CPDOC, 2004. Disponível em: http:/cpdoc.fgv.br/producao/dossies/ AEraVargas2/artigos/AlemDaVida/CartaTestamento. Acesso em: 01 jun 2014. MAINGUENEAU, D. Doze conceitos em análise do discurso. Rio de Janeiro: Parábola, 2010. . Cenas da enunciação. Curitiba: Criar, 2006. Cena da enunciação. In: CHARAUDEAU, P.; MAINGUENEAU, D. Dicionário de Análise do Discurso. São Paulo: Contexto, 2004, p. 95-97. . Análise de textos de comunicação. São Paulo: Cortez, 2001.

MAZZEI, A.J.F. O legado de Vargas. História Viva. Disponível em: http://www2.uol. com.br/historiaviva/reportagens/o_legado_de_vargas.html. Acesso em: 01 jun. 2014. MEMORIAL GETÚLIO VARGAS. Carta-testamento. Disponível em: http://www0.rio. rj.gov.br/memorialgetuliovargas/conteudo/expo8.html. Acesso em: 01 jun. 2014. MICHAELIS: moderno dicionário da língua portuguesa. São Paulo: Companhia Melhoramentos, 1998.

NASCIMENTO. J.V; CANO, M.R.O. Cenas da enunciação em textos jornalísticos: o caso da "ditabranda" na Folha de S. Paulo. Veredas. Juiz de Fora, PPG LINGUÍSTICA/ UFJF, v. 1, 2011, p. 398-411.

NETO, Lira. Getúlio: da volta pela consagração popular ao suicídio (1945-1954). São Paulo: Companhia das Letras, 2014. 
. Por que Getúlio se matou? Aventuras na História: para viajar no tempo. 2004.

Disponível em: http://guiadoestudante.abril.com.br/aventuras-historia/getulio-sematou-433744.shtml. Acesso em: 01 jun. 2014.

RODRIGUES et al. A carta-testamento de Getúlio Vargas (1882-1954): genericidade e organização textual no discurso político. Filologia e Linguística Portuguesa, n.1, v. 2, p. 285-307, 2012.

Anexo

Carta-Testamento

(1) Mais uma vez, a forças e os interesses contra o povo coordenaram-se e novamente se desencadeiam sobre mim. (2) Não me acusam, insultam; não me combatem, caluniam, e não me dão o direito de defesa. (3) Precisam sufocar a minha voz e impedir a minha ação, para que eu não continue a defender, como sempre defendi, o povo e principalmente os humildes.

(4) Sigo o destino que me é imposto. (5) Depois de decênios de domínio e espoliação dos grupos econômicos e financeiros internacionais, fiz-me chefe de uma revolução e venci. (6) Iniciei o trabalho de libertação e instaurei o regime de liberdade social. (7) Tive de renunciar. (8) Voltei ao governo nos braços do povo. (9) A campanha subterrânea dos grupos internacionais aliou-se à dos grupos nacionais revoltados contra o regime de garantia do trabalho. (10) A lei de lucros extraordinários foi detida no Congresso. (11) Contra a justiça da revisão do salário mínimo se desencadearam os ódios. (12) Quis criar liberdade nacional na potencialização das nossas riquezas através da Petrobrás e, mal começa esta a funcionar, a onda de agitação se avoluma. (13) A Eletrobrás foi obstaculada até o desespero. (14) Não querem que o trabalhador seja livre.

(15) Não querem que o povo seja independente. (16) Assumi o Governo dentro da espiral inflacionária que destruía os valores do trabalho. (17) Os lucros das empresas estrangeiras alcançavam até 500\% ao ano. (18) Nas declarações de valores do que importávamos existiam fraudes constatadas de mais de 100 milhões de dólares por ano. (19) Veio a crise do café, valorizou-se o nosso principal produto. (20) Tentamos defender seu preço e a resposta foi uma violenta pressão sobre a nossa economia, a ponto de sermos obrigados a ceder.

(21) Tenho lutado mês a mês, dia a dia, hora a hora, resistindo a uma pressão constante, incessante, tudo suportando em silêncio, tudo esquecendo, renunciando a mim mesmo, para defender o povo, que agora se queda desamparado. (22) Nada mais vos posso dar, a não ser meu sangue. (23) Se as aves de rapina querem o sangue de alguém, querem continuar sugando o povo brasileiro, eu ofereço em holocausto a minha vida.

(30) Ao ódio respondo com o perdão.

(31) E aos que pensam que me derrotaram respondo com a minha vitória. (32) Era escravo do povo e hoje me liberto para a vida eterna. (33) Mas esse povo de quem fui escravo não mais será escravo de ninguém. (34) Meu sacrifício ficará para sempre em sua alma e meu sangue será o preço do seu resgate. (35) Lutei contra a espoliação do Brasil. (36) Lutei contra a espoliação do povo. (37) Tenho lutado de peito aberto. (38) O ódio, as infâmias, a calúnia não abateram meu ânimo. (39) Eu vos dei a minha vida. (40) Agora vos ofereço a minha morte. (41) Nada receio. (42) Serenamente dou o primeiro passo no caminho da eternidade e saio da vida para entrar na História. (MEMORIAL GETÚLIO VARGAS) 